\title{
Intra-annual variation in rainfall and it's influence of the adult's Cyprideis spp (Ostracoda, Crustacea) on a eutrophic estuary (Guanabara Bay, Rio de Janeiro, Brazil).
}

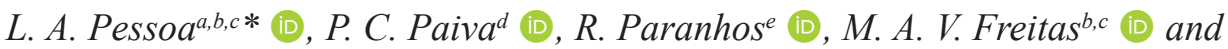 \\ C. A. Echeverría ${ }^{a, b, c}$
}

aLaboratório de Pesquisas Costeiras e Estuarinas - LABCOEST, Universidade Federal do Rio de Janeiro - UFRJ, Ilha do Fundão, Av. Pedro Calmon, CEP 21941-596, Rio de Janeiro, RJ, Brasil

'Instituto Virtual Internacional de Mudanças Globais - IVIG, Instituto Alberto Luiz Coimbra de Pós-Graduação e Pesquisa de Engenharia - COPPE, Universidade Federal do Rio de Janeiro - UFRJ, Ilha do Fundão, Av. Pedro Calmon, CEP 21941-596, Rio de Janeiro, RJ, Brasil

'Programa de Planejamento Energético e Ambiental - PPE, Instituto Alberto Luiz Coimbra de Pós-Graduação e Pesquisa de Engenharia - COPPE, Universidade Federal do Rio de Janeiro - UFRJ, Centro de Tecnologia, Ilha do Fundão,

Av. Athos da Silveira Ramos, CEP 21941-909, Rio de Janeiro, RJ, Brasil

${ }^{\mathrm{d}}$ Laboratório de Polychaeta, Departamento de Zoologia, Instituto de Biologia, Universidade Federal do Rio de Janeiro UFRJ, Centro de Ciências da Saúde, Ilha do Fundão, Av. Carlos Chagas Filho, CEP 21941-590, Rio de Janeiro, RJ, Brasil

éaboratório de Hidrobiologia, Departamento de Biologia Marinha, Instituto de Biologia, Universidade Federal do

Rio de Janeiro - UFRJ, Centro de Ciências da Saúde, Ilha do Fundão, Av. Carlos Chagas Filho,

CEP 21941-590, Rio de Janeiro, RJ, Brasil

*e-mail: leandro.amaro.pessoa@gmail.com

Received: November 7, 2018 - Accepted: February 12, 2019 - Distributed: May 31, 2020

(With 5 figures)

\begin{abstract}
Spatial and temporal distribution of two species of adult's ostracods (Cyprideis sp. and Cyprideis salebrosa) were studied as a function of the rainfall patterns in the Guanabara Bay, Rio de Janeiro, Brazil. Samples were taken in ten stations, along six surveys representing three periods (Dry, Early and Late Rainy) for two years. Stations were nested in four areas (Outer, Central, EPA Guapimirim and Impacted). The bottom water (temperature, salinity, dissolved oxygen and oxygen saturation) were measured in each area to characterize the influence of seasonal variations by rainfall. Cyprideis sp. and Cyprideis salebrosa showed patterns distribution to seasonality/surveys ( $\mathrm{p}=0,002$ and $\mathrm{p}<0,001$, respectly). The spatial distribution of Cyprideis sp was significantly different areas studied $(\mathrm{p}<0.001)$ indicated well defined areas and distribution in along of the surveys. However, C. salebrosa showed homogeneous distribution in along of the areas within of each survey $(\mathrm{p}<0.001)$. Redundancy Analysis (RDA) for the two years evidenced environment preference of the Cyprideis sp. for areas with marine conditions (high influence for channel central) and C. salebrosa for brackish water (high influence of the rivers). This observation reinforces of the existence of areas created by the seasonality of pluviometric regime, a possible dispersion of the adult's ostracods and possibility the use with bioindicators.
\end{abstract}

Keywords: bioindicators, macrobenthic, climate change, sediments, soft-bottom and sublittoral.

\section{Variação intra-annual na chuva e a sua influência nos adultos de Cyprideis spp (Ostracoda, Crustacea) em um estuário eutrofizado (Guanabara Bay, Rio de Janeiro, Brasil).}

\section{Resumo}

A distribuição espacial e temporal de duas espécies de ostracodes adultos (Cyprideis sp. e Cyprideis salebrosa) foi estudada em função do padrão pluviométrico na Baía de Guanabara, Rio de Janeiro, Brasil. As amostras foram coletadas em dez estações ao longo de seis campanhas, representando três períodos (Seco, Pré e Pós Chuvoso) por dois anos. As estações foram agrupadas em quatro áreas (Externo, Central, EPA Guapimirim e Impactado). A água do fundo (temperatura, salinidade, oxigênio dissolvido e saturação de oxigênio) foi medida em cada área para caracterizar a influência das variações sazonais pela chuva. Cyprideis sp. e Cyprideis salebrosa mostrou distribuição de padrões para sazonalidade/campanhas $(\mathrm{p}=0,002$ e $\mathrm{p}<0,001$, respctivamente). A distribuição espacial de Cyprideis sp. foi significativamente diferente das áreas estudadas $(\mathrm{p}<0,001)$ indicou áreas bem definidas e distribuição ao longo das campanhas. No entanto, C. salebrosa mostrou distribuição homogênea ao longo das áreas dentro de cada campanha 
( $\mathrm{p}<0,001$ ). A Análise de Redundância (RDA) para os dois anos evidenciou a preferência ambiental dos Cyprideis sp. para áreas com condições marinhas (alta influência para o canal central) e C. salebrosa para águas salobras (alta influência dos rios). Essa observação reforça a existência de áreas criadas pela sazonalidade do regime pluviométrico, uma possível dispersão dos adultos de ostracodes e a possibilidade do uso como bioindicadores.

Palavras-chave: bioindicadores, macrobenthos, mudança climática, sedimentos, fundo não-consolidado, infralitoral.

\section{Introduction}

In tropical estuaries, benthic biological processes are usually strongly influenced by the characteristics of the water mass above the communities, as well as the granulometric bottom structure (Day et al., 1989; Little, 2000; Gray and Elliot, 2009). Communities parameters reflect these conditions through variations in species composition and relative dominance, due to species-specific physiological tolerance to several factors, allied to particular dispersion pattern strategies (Day et al., 1989; Gray and Elliot, 2009; Echeverría et al., 2010; Neves et al., 2013; Pereira et al., 2013; Magalhães et al., 2014). The latter are modulated, in turn, by physical and chemical factors during adult's dispersion and settlement events (Alongi, 1989; Day et al., 1989; Valiela, 1995; Echeverría et al., 2010; Pereira et al., 2013).

Climatic patterns in tropical coastal and estuarine areas are mainly characterized by the alternance of historically well defined rainy and dry periods (Amador, 1997; INMET, 2008; Knauss, 2005; Marengo et al., 2009; Amador, 2012). Freshwater runoff from rivers is one of the main natural variation factors in tropical and subtropical estuaries, implying, in certain cases, in a wide seasonality of environmental parameters (Alongi, 1989; Day et al., 1989; Mayr et al., 1989; Paranhos and Mayr, 1993; Paranhos et al., 1993; Passadore et al., 2007). Circulation in a tropical estuarine system is characterized by the presence of two main mutually-interacting water masses (Pritchard, 1955; Pritchard, 1967; Knauss, 2005; Prandle, 2009). As the tide rises, colder, saltier, and consequently denser seawater penetrates below the warmer, fresher, less dense, estuarine water. The level of mixing is used to define the model of local circulation (Pritchard, 1955; Pritchard, 1967; Knauss, 2005; Prandle, 2009). Thus, the extent of seawater influence throughout the estuary is river-runoff dependent, especially in a microtidal environment, as Guanabara Bay, Rio de Janeiro, Brazil (Mayr et al., 1989; Amador, 1997; Kjerfve et al., 1997; Amador, 2012). When the river-runoff is reduced, as in the dry season (lower rainfall), seawater influence extends throughout the entire estuarine body (Mayr et al., 1989; Paranhos and Mayr, 1993; Paranhos et al., 1993; Amador, 1997; Kjerfve et al., 1997; Amador, 2012). On the contrary, in the wet season (higher rainfall), the higher river-runoff influences the entrance of marine water, thus limiting the extension of the salt wedge (Mayr et al., 1989; Paranhos and Mayr, 1993; Paranhos et al., 1993; Kjerfve et al., 1997). This balance between marine input, regulated by river-runoff, and tide amplitude, results in a characteristic seasonal variation in Guanabara Bay, which presents an extremely wide watershed (Mayr et al., 1989; Amador, 1997; Kjerfve et al., 1997; Amador, 2012).

An increase in runoff in tropical bays enhances the input of sediment, organic matter, heavy metals, organochlorates, and other anthropically originated residuals, thereby increasing the bottom bacterial activity (Paranhos et al., 1998; Crapez et al., 2000; Carreira et al., 2001; Paranhos et al., 2001; Baptista Neto et al., 2005). Several rivers are polluted around the Guanabara Bay, manly because of populous regions which discharge high amounts of organic matter. Approximately 55 rivers discharge in the Guanabara Bay, some of them are highly polluted (Amador, 1997; Kjerfve et al., 1997; Paranhos et al., 1998; Crapez et al., 2000; Carreira et al., 2001; Paranhos et al., 2001; Baptista Neto et al., 2005; Brito et al., 2006; Amador, 2012).

During the process of carbonic chains (organic matter, petroleum residuals and others) are degraded, inducing the consumption of dissolved oxygen, both from the sediment and the water column, resulting in an increase in substrata acidity and a reduction in dissolved oxygen (Paranhos et al., 1998; Little, 2000; Paranhos et al., 2001; Mendonça Filho et al., 2003; Gray and Elliot, 2009). These disturbances generate changes in the benthic community structure. These ecological conditions are observed in ecosystems that are recovering from a disturbance followed richness and diversity decrease, appearance of opportunistic species, and others (Rakocinski et al., 1997; Brown et al., 2000; Rosenberg, 2001; Bergin et al., 2006; Gray and Elliot, 2009; Echeverría et al., 2010; Pereira et al., 2013).

Ostracods are small crustaceans with a bivalved carapace that when accumulated in the sediment may be relatively transparent, translucent or opaque. Their size ranges from 0.2 to $2.0 \mathrm{~mm}$ (Brandão et al., 2018). They are important in the environmental assessment because they are particularly immobile in the sediment, not being able to distance itself actively from local impacts (Mezquita et al., 1999; Vilela et al., 2013). Thus, the analysis of the composition, distribution and diversity of the ostracod fauna allows its use as indicators of environmental impact and system recovery (Schratzberger et al., 2003; Vilela et al., 2013; Keats and Osher, 2007). They colonize a wide range of aquatic environments (Frenzel and Boomer, 2005), most of the species are benthic and many occur in calm water environments where the clay or fine bottom sand is rich in organic matter (Van Morkhoven, 1962; Armonies and Hellwig, 1986; Brown et al., 2000). However, the granulometric variable as lower natural change over time, and bottom water variable is altered at each cycle tidal, runoff, wind, and others (Day et al., 1989; Gray and 
Elliot, 2009). The most frequent habitat of several recent ostracods is the water-sediment interface or immediately below, being thus vulnerable to the direct influence of the parameters of both the bottom water and the sediment (Carbonel, 1988).

Ostracods are also used as bioindicators of salinity, temperature, dissolved oxygen, organic matter and metal concentration and others (Ruiz et al., 1997; Modig and Ólafsson, 1998; Curry, 1999; Vilela et al., 2003; Ruiz et al., 2004; Frenzel and Boomer, 2005; Nagorskaya and Heyser, 2005; Bergin et al., 2006; Ruiz et al., 2006). Cyprideis spp. has been tested as indicators of environmental parameters, and their physiology is sufficiently understood to allow their use in monitoring programs (Curry, 1999; Debenay et al., 2003; Frenzel and Boomer, 2005; Vilela et al., 2003).

Knowledge about the spatial and temporal distribution of species Cyprideis spp. may provide subsidies to evaluate assessment and monitoring environmental alterations related to sediments, such as dredging, sediment discharge and others. These environmental conditions exert an influence on benthic communities, by creating a mosaic with different dynamics, according to their relative position within the bay (Ghiselli Junior et al., 2003; Vilela et al., 2003; Ghiselli Junior, 2006; Echeverría et al., 2010; Pereira et al., 2013). The Cyprideis spp in the Guanabara Bay are abundants live in and above the sediments and possibly respond to seasonal variations (Sola and Paiva, 2001; Ghiselli Junior et al., 2003; Vilela et al., 2003; Ghiselli Junior, 2006).

The main objectives are to characterize the spatial distribution of the two dominant recent adult's ostracods species (Cyprideis salebrosa and Cyprideis sp.) from the soft-bottom sublittoral and to study the relationship of these species with bottom water parameters and rainfall in an estuarine system the Guanabara Bay along two years.

\section{Materials and Methods}

\subsection{Study area}

Guanabara Bay, located in the State of Rio de Janeiro between $22^{\circ} 40^{\prime}$ and $23^{\circ} 00^{\prime}$ South and $43^{\circ} 00^{\prime}$ and $43^{\circ} 20^{\circ}$ West, comprises $377 \mathrm{~km}^{2}$, excluding the islands (Figure 1, Amador, 1997). According to circulation-model criteria, the bay is classified as a predominantly saline-water estuarine system with semi-diurnal tides (Amador, 1997). Several authors (Mayr et al., 1989; Paranhos and Mayr, 1993; Paranhos et al., 1993; Valentin et al., 1999) observed that the prevailing seasonal pattern of abiotic parameters consists of a reduction in temperature and increase in salinity from May to September (Dry season), and the reverse from October to April (Rainy season). The grain-size pattern varies spatially, with a predominance of silt and clay and high organic content in the inner bay, with gradual changes towards the entrance, where there is a concentration of coarse sand and low organic matter content (Quaresma et al., 2000).

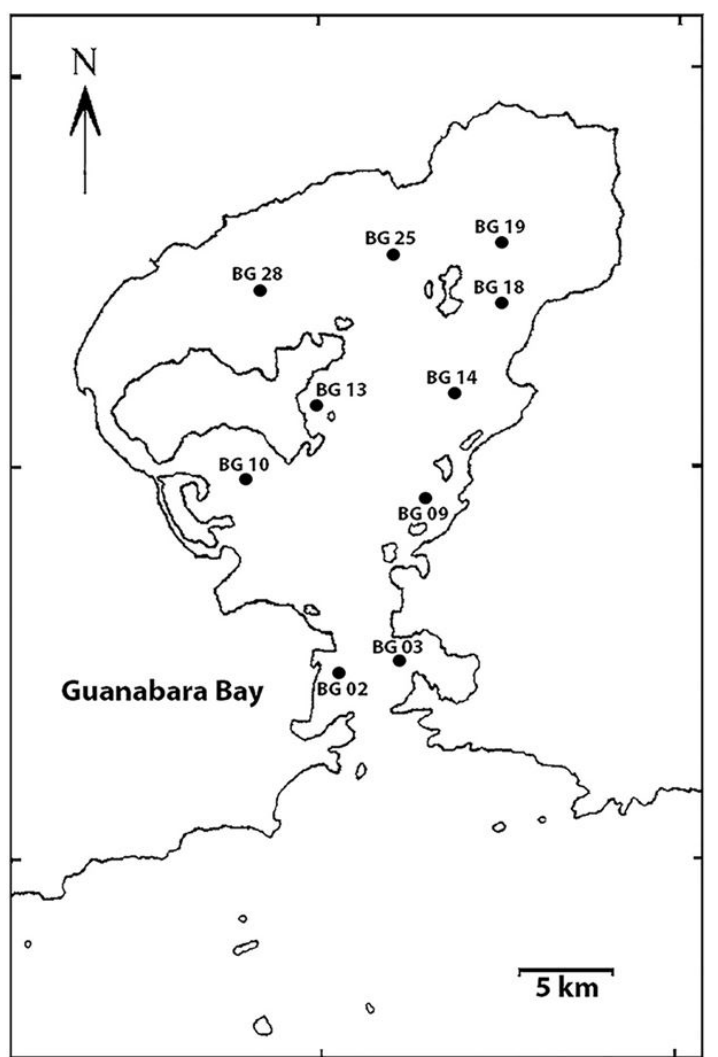

Figure 1. Study area and stations selected for sampling in the Guanabara Bay.

\subsection{Sampling}

Samples were taken during a two-year period from 2005 to 2007, in six periods planned according to historical rainfall records (1961-1990 Climatologic Normal), and using data supplied by the National Institute of Meteorology (INMET - Figure 2). In Rio de Janeiro, there is a marked seasonality in rainfall, characterized by a rainy season in the summer and a dry in the winter (Figure 2). Thus, periods were defined comprehending three periods over two years: (D) Dry, (ER) Early Rainy and (LR) Late Rainy seasons, in order to assess the effect of cumulative rainfall on benthic communities (Figure 2). Ten sampling stations were defined and nested in areas according to similar environmental conditions along the estuarine system (Mayr et al., 1989; Paranhos et al., 1993). Thus, the four areas are: Outer (BG 02 and BG 03); Central (BG 09, BG 13 and BG 14); EPA Guapimirim (Enviromental Protected Area Guapimirim / BG 18 and BG 19) and Impacted (BG 10, BG 25 and BG 28 - Figure 1). These areas were chosen according to their previously described environmental characteristics along the estuarine systems, such as: Depth, granulometry, circulation and water physical-chemical (Meniconi et al., 2012a; Mayr et al., 1989; Paranhos et al., 1993; Amador, 1997; Valentin et al., 1999; Amador, 2012).

Benthic samples were taken using a Gravity corer $\left(0.0078 \mathrm{~m}^{2}\right.$ for sample). Ten samples were taken at each 


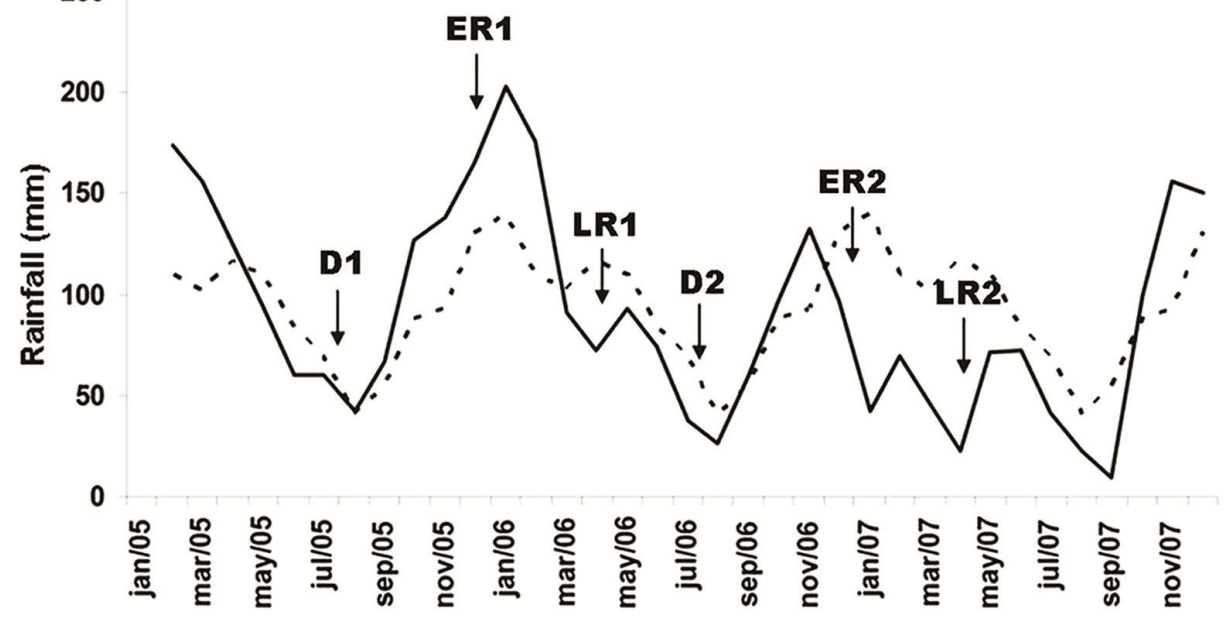

Figure 2. Climatological normal (1961-1990) in Rio de Janeiro region (dashed line) and the mean monthly accumulated rainfall (continuous line) during the study period (2005, 2006 and 2007). The samplings occurred in dry (D1: July 2005; D2: July 2006), early rainy (ER1: December 2005; December 2006) and late rainy (LR1: April 2006; LR2: April 2007) seasons. Data modified from INMET (2008). Source: inmet.gov.br/html/observacoes.php

station for six surveys (total numbers of samples, $\mathrm{n}=600$ ), geo-referenced throughout the bay and distributed from the entrance to the inner part of the bay (Figure 1). Stations were selected in according to batimetric (between four and seven meters depth). Such a narrow bathymetric range was chosen to facilitate the comparison of biological communities throughout a gradient of physical variables not linked to depth. The inner (EPA Guapimirim and Impacted stations) and Central (with exception of BG 09) stations were composed of fine sediments (silt-clay) (Quaresma et al., 2000), where the sampler performance was effective. At Outer stations BG 02 and BG 03 (sand), as well as BG 09 (very fine sand-clay), sampling was undertaken by skin-diving, due to the low efficiency of the Gravity corer in sandy sediments. Nonetheless, direct comparison of data was possible, as the corer used in skin-diving sampling was the same as that used in the Gravity corer.

The bottom water samples were collected twice a month at all stations, the temperature was measured with a graduate thermometer. Salinity and dissolved oxygen were determined, respectively, by chlorinity and Winkler methods. Water chemistry variables were determined in triplicate using standard oceanographic methods (Grassholf et al., 1999; Parsons et al., 1984). Temperature and salinity were measured during sampling using a Multi Probe System YSI 556 (YSI Incorporated, USA). Salinity was also determined by titration of chlorine against standard seawater (Ocean Scientific International Ltd. - OSIL). Dissolved oxygen was determined by Winkler titration. Twice weekly samples of background water were retrieved at the stations of original collection. All georeferenced data, together with the results from other projects, are available in the database of the Guanabara Bay Environmental Assessment Program (Meniconi et al., 2012b).
The samples were washed in $500 \mu \mathrm{m}$ mesh-size sieves, and the material retained fixed in $70 \%$ alcohol. The material was sorted and identified in the laboratory using stereoscopic microscope. Since $500 \mu \mathrm{m}$ mesh was used, the criteria for defining macrobenthic population patterns (recent adult's ostracods), here observed, represent the late stages in development or last instars of the ostracods adults (Howe et al., 1961; Kesling, 1961). Even though most ostracods meiofaunal-sized (including the estuarine ones), the focus of the present study are two species of Cyprideis with adult size larger than $500 \mu \mathrm{m}$. in Guanabara Bay, it is common to located specimens with a sufficient size to fit into the macrobenthic category (Sola and Paiva, 2001; Ghiselli Junior et al., 2003; Vilela et al., 2003; Ghiselli Junior, 2006).

\subsection{Data analysis}

Bottom water analysis was undertaken after gathering abiotic data (temperature, salinity, dissolved oxygen and oxygen saturation) from the stations within each of the areas of the bay, namely in this paper as: Outer, Central, EPA Guapimirim and Impacted. Temporal analysis of bottom water was in accordance with seasonal rainfall dynamics, as observed on past years, according climatologic normal (Inter-annual variation - Figure 2) and following the same sampling design as the macrobenthos. Bottom-water data were grouped in time, taking into consideration the four months immediately preceding each macrobenthic sampling season: (D) Dry; (ER) Early Rainy and (LR) Late Rainy season.

Ostracod densities were $\log$ transformed $(\log (x+1))$, in order to improve variance homogeneity before data analysis. A Partly-Nested ANOVA (analogous to a split-plot design) was undertaken, with the fixed variables Areas and 
Surveys crossed, and the variable 'Stations' nested within Areas and crossed with Surveys (Quinn and Keough, 2003).

Redundancy Analysis (RDA) was used for the interpretation of the interactions of environmental variables (the code is represented for letter (Survey - I, II, III, IV, V and VI) and number (Station), for example V19 is the variable Survey five and Station nineteen) with the two species (Cyprideis sp. and Cyprideis salebrosa) in all surveys (Borcard et al., 2011). BG 02 and BG 03 stations were excluded, in order to reduce the analysis noise since no Cyprideis individuals of both species were found.

The analyzes (Nested ANOVA and Redundancy Analysis) were perfomed using R statistical environment (R Development Core Team, 2008).

\section{Results}

A seasonal pattern was apparent in bottom water variables, within the typical, characteristic circulation pattern of tropical and subtropical estuaries. The highest salinity, dissolved oxygen and oxygen saturation were always in the outer bay, during dry periods, and with relatively low temporal variation (Figure 3 ). The lowest salinity was always observed in the inner areas during early rainy season (ER1 and ER2), whereas higher temperatures and lower levels of both dissolved oxygen and oxygen saturation occurred in late rainy season (LR1 and LR2) (Figure 3). A clear spatial gradient was apparent on bottom water characteristics with salinity constantly decreasing and seasonal variation increasing towards the entrance (Outer) to the inner bay (Impacted), where the lower and temporally variable salinities are indicators of the seasonal inflow of river water inside the bay itself (Figure 3).

Cyprideis was absent in stations BG 02 and BG 03, located near the entrance of the bay. These stations differed from the remaining, regarding to sediment composition (mainly sand - Quaresma et al., 2000). In all other stations (BG 09, BG 10, BG 13, BG 14, BG 18, BG 19, BG 25 and BG 28), Cyprideis species were observed in at least one season because of the presence of fine sediments with high organic matter concentration (Quaresma et al., 2000 - Figure 4).

Population densities of the two species were higher in LR1 (Late Rainy season - April/2006). with both species occurring at all the stations, with the exception of BG 02 and BG 03 (Figure 4). The highest mean densities in this study were observed at stations BG 09 for Cyprideis sp. (7,359 ind. $\left.\mathrm{m}^{-2}\right)$, and BG 19 for C. salebrosa $\left(1,064\right.$ ind. $\left.\mathrm{m}^{-2}\right)$, both in LR1 (Figure 4). The lowest mean density for Cyprideis sp. was 38 ind. $\mathrm{m}^{-2}$ in BG 25 and for C. salebrosa 70 ind. $\mathrm{m}^{-2}$ in BG 09, also in LR1. Both species occurred together in all the seasons in stations BG 09, BG 13 and BG 14 only (Figure 4).

The distribution of Cyprideis sp. and Cyprideis salebrosa showed relationship to the seasonality/surveys $(\mathrm{p}=0,002$ and $\mathrm{p}<0,001$, respectively). Cyprideis $\mathrm{sp}$ was significant in the
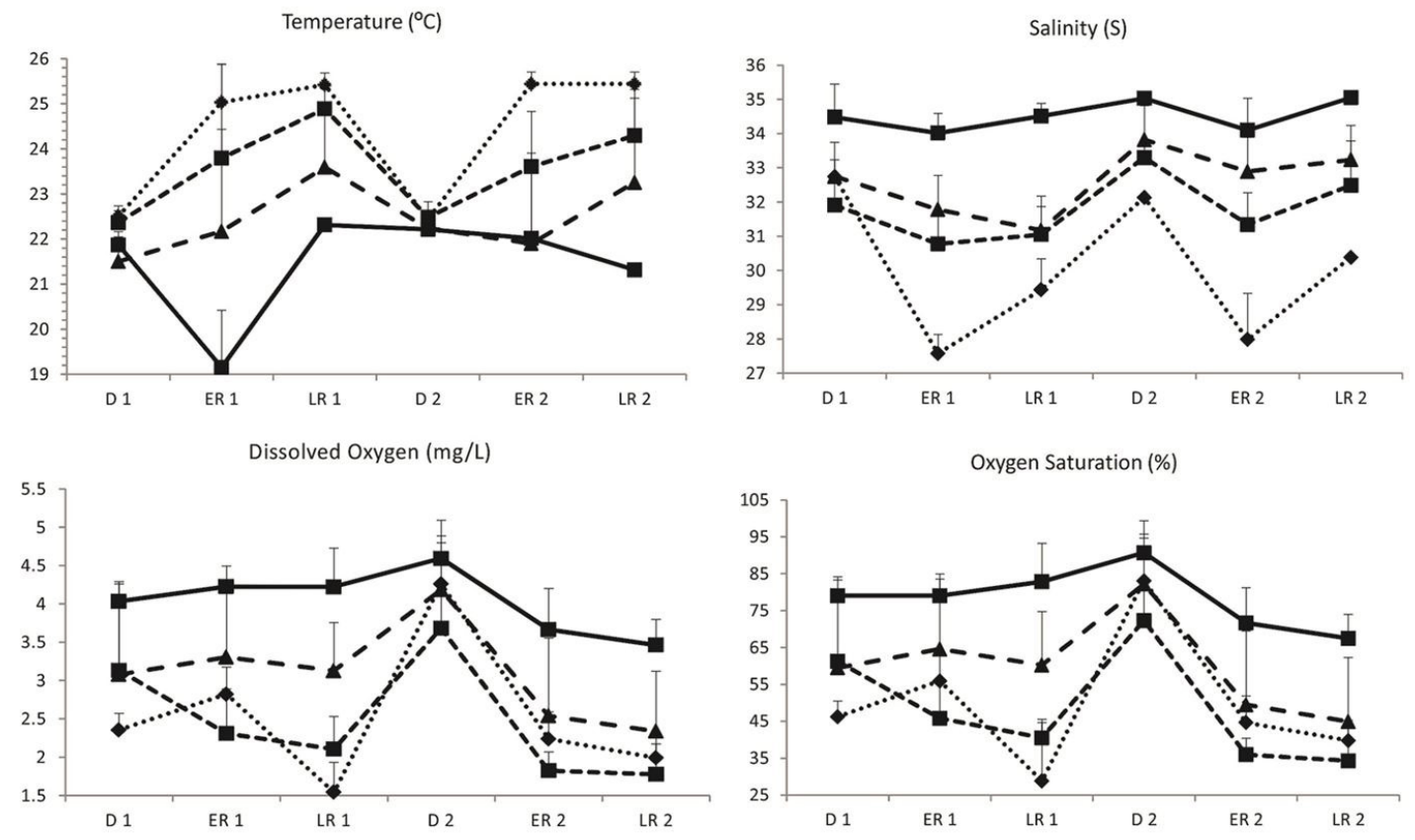

$\cdots \bullet \cdot$ EPA Guapimirim $-\square-$ Impacted $\rightarrow \Delta$ Central

Figure 3. Abiotic bottom water data from all the seasons (D - Dry season, ER - Early Rainy season and LR - Late Rainy season) in the four sectors of the Guanabara Bay (EPA Guapimirim - BG 18 and BG 19; Impacted - BG 10, BG 25 and BG 28 ; Central - BG 09, BG 13 and BG 14; Outer - BG 02 and BG 03). 
spatial distribution areas $(\mathrm{p}<0.001)$ indicated well defined areas and distribution in along of the surveys. However, C. salebrosa showed homogeneous distribution among the areas within of each survey $(p<0.001)$. The density of Cyprideis sp. presented spatial variation only among Stations and among Surveys, there were no interactions between Areas and Surveys or Stations and Surveys, indicating a homogenous pattern between different areas of the bay (Table 1).

Nevertheless, as regards C. salebrosa, significant seasonal variation among Surveys was observed being this variation different among Areas but not among Stations. This indicates that sampling stations within each area (Area) of the bay were homogeneous as regards C. salebrosa densities and that there is a seasonal variation among the different regions of the bay (Table 2).

This variation was due to the decrease in density at the early wet season (summer) in the inner areas of the bay, being the decrease stronger in the Impacted area and less intense in the EPA Guapimirim.

The redundancy Analysis for the two years (2005-2007/Figure 5) showed that both species (Cyprideis salebrosa and Cyprideis sp.) show different environmental preferences of the Cyprideis sp. Is directly related to both higher salinity and dissolved oxygen, which are prevalent in the Central sector. Conversely, Cyprideis salebrosa showed a higher dominance in the inner stations (BG 18, BG 19, BG 25 e BG 28) of the Guanabara Bay, which

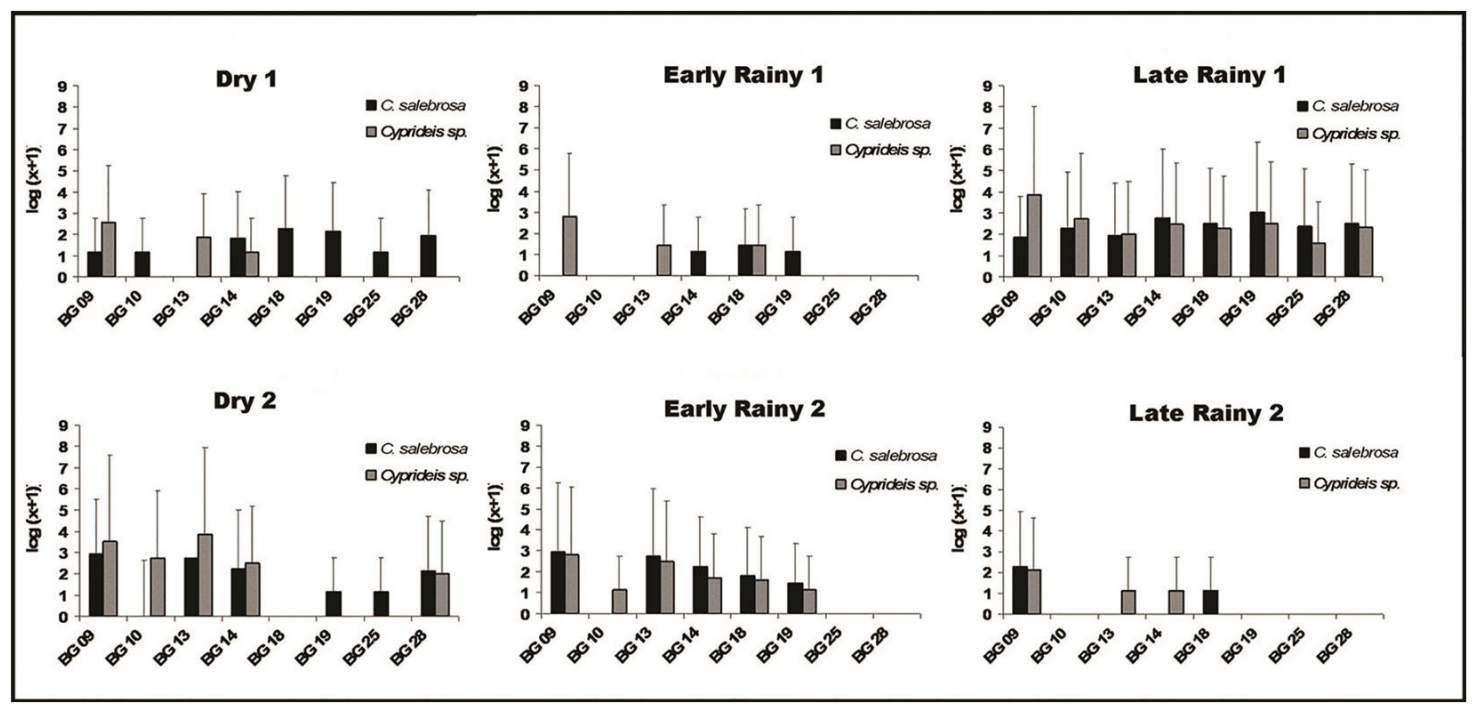

Figure 4. Mean density normalized $(\log (\mathrm{x}+1))$ and standard deviation of Cyprideis sp. and Cyprideis salebrosa in each station along the seasons $(n=600)$.

Table 1. Results of the Partly-Nested Analysis of Variance in Cyprideis sp. density ( $\mathrm{p}<0.05$ significant values in bold-type).

\begin{tabular}{lrcccc}
\hline \multicolumn{1}{c}{ SOURCE } & S.S. & D.F. & M.S. & F-RATIO & P \\
\hline Survey & 21.180 & 5 & 4.236 & 5.153 & $\mathbf{0 . 0 0 2}$ \\
Group & 22.278 & 2 & 11.389 & 3.846 & 0.097 \\
Survey x Group & 7.541 & 10 & 0.754 & 0.917 & 0.533 \\
Station (Group) & 14.803 & 5 & 2.961 & 4.802 & $<\mathbf{0 . 0 0 1}$ \\
Survey x Station (Group) & 20.556 & 25 & 0.822 & 1.333 & 0.132 \\
Error & 266.349 & 432 & 0.617 & & \\
\hline
\end{tabular}

Table 2. Results of the Partly Nested Analysis of Variance in C. salebrosa density. ( $p<0.05$ significant values in bold type).

\begin{tabular}{lrcrrr}
\hline \multicolumn{1}{c}{ SOURCE } & S.S. & D.F. & M.S. & F-RATIO & P \\
\hline Survey & 14.808 & 5 & 2.962 & 13.106 & $<\mathbf{0 . 0 0 1}$ \\
Group & 2.220 & 2 & 1.110 & 2.106 & 0.217 \\
Survey x Group & 15.134 & 10 & 1.513 & 6.694 & $<\mathbf{0 . 0 0 1}$ \\
Station (Group) & 2.633 & 5 & 0.527 & 1.360 & 0.238 \\
Survey x Station (Group) & 5.643 & 25 & 0.226 & 0.583 & 0.938 \\
Error & 167.267 & 432 & 0.387 & & \\
\hline
\end{tabular}




\section{RDA (2005 - 2007)}

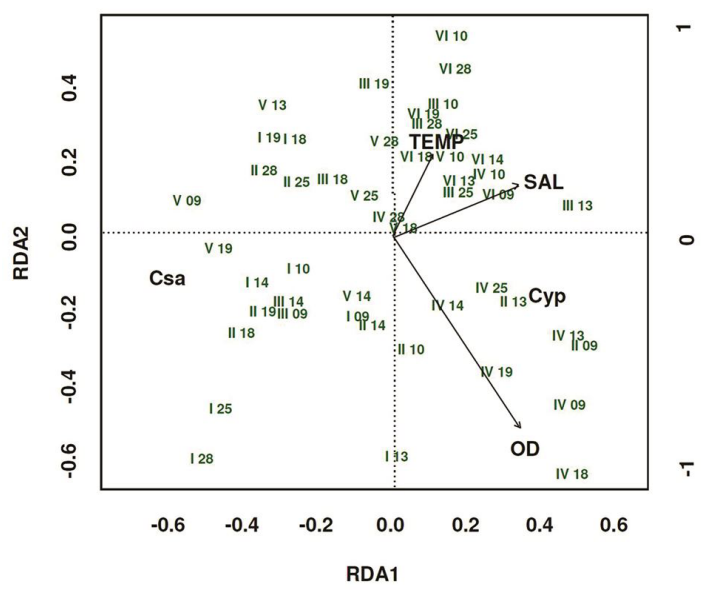

Figure 5. Redundancy Analysis (RDA) in all seasons (2005-2007). Species: Csa (Cyprideis salebrosa) and Cyp (Cyprideis sp.) and abiotic bottom water: SAL (salinity), TEMP (temperature) and OD (dissolved oxygen).

are associated to lower salinity and frequent events of anoxia/hypoxia.

These atypical rainfalls because the second year was a low pluviosity promoted a change in the biotic structure and allowed a wider distribution of Cyprideis sp. (marine conditions) for the Central, EPA Guapimirim and Impacted sector owing to the more widespread adequate environmental conditions for this species.

\section{Discussion}

In the inner part of the bay, the seasonal patterns of bottom water salinity and temperature variation clearly demonstrated the seasonal influence of river-input, mainly during the wet season. The highest salinities, associated to lower temperatures and relatively high concentration of dissolved oxygen, occurred during the dry season. This was inversely observed during the wet season of this following year (Figures 2 and 3 ). This pattern could be observed mainly in the areas Impacted and EPA Guapimirim. In the Central area, the pattern implied a mixture of external (marine) waters with internal estuarine waters, as well as poorly defined seasonal variation were observed. In the Outer area, the typical marine pattern was constant (Figures 2 and 3 ).

The high occurrence of C. salebrosa mainly in stations located near EPA Guapimirim (BG 14, BG 18 and BG 19), where the river runoff is expressive during rainy periods, implies that this species is tolerant to variations in salinity, as well as several abiotic factors modulated by river runoff, such as temperature, dissolved oxygen, nutrients, organic matter, fine sediment, and anthropic and industrial pollution, a result of washout from the metropolitan areas (Meniconi et al., 2012a, b; Figures 4 and 5).

Cyprideis sp. occurred mainly in stations BG 13 and BG 14 (Figures 4 and 5), classified herein as Central, due to their location and hydrological characteristics (Figures 1 and 3). Nevertheless, the densities of both species were also high in station BG 09 (Figure 4), which differed from the remainder by the significant fraction of fine sand and clay in the bottom (Quaresma et al., 2000). During flood tides, there is the strong influence of nearness to the central channel to be considered, whereas during the ebb, there is an increase in riverine organic matter (Rosenberg, 2001). As an example, during LR1 (April 2006), high densities of both species were recorded in all stations, probably due to the increase in organic matter deposition and river-originated nutrients, caused by the preceding rainy months (Meteorology National Institute - INMET / Figure 2). However, when compared to LR2 (April 2007), when a repetition of the same population pattern would be expected, significant differences were found. A possible explanation could be the unusually low rainfall observed during the preceding months, thus altering the physical and chemical characteristics of the bay, when compared to the seasonal pattern observed during the first year of the study (Meniconi et al., 2012a, b).

Through temporal analysis, Cyprideis sp. presented a similar seasonal variation throughout the entire area. This species preferentially occurs in areas under marine influence (Benson, 1959; Benson, 1961; Anadón et al., 2002; Boomer and Eisenhauer, 2002). Could be still further modulated by the widespread influence of the salt wedge, enhanced by the presence of the extensive central channel until end of the bay (Mezquita et al., 1999; Debenay et al., 2003; Nagorskaya and Heyser, 2005, Figures 3, 4, 5 and Table 1).

However, our analyses suggest that the abundance of $C$. salebrosa varies seasonally in along the bay (Figures 3, 4, 5 and Table 2). Probably the outcome of the variable influence of river-runoff in the inner areas, the mixture with marine waters in the Central, and the influence of seawater in tidal events (Carbonel, 1988; Curry 1999; Passadore et al., 2007). Lower densities in the internal areas could be associated to high anthropic impacts, caused by domestic and industrial sewage discharge, associated to restricted circulation in the Impacted area (Mayr et al., 1989; Paranhos et al., 1998; Modig and Ólafsson, 1998; Carreira et al., 2001; Paranhos et al., 2001; Machado et al., 2002; Mendonça Filho et al., 2003). On the other hand, in EPA Guapimirim, an Environmental Protection Area, impacts can be considered less intense, in spite of the constant runoff of several nearby rivers and the high concentrations of organic matter (Carreira et al., 2001). Patterns in the Central area were more complex, as this comprised stations under the influence of changing water conditions, with pronounced marine influence modulated by tidal cycles and winds, leading to intense variations in salt wedge extent (Paranhos et al., 1993; Paranhos and Mayr, 1993).

Ghiselli Junior et al. (2003) and Ghiselli Junior (2006) studied meiofaunal ostracods in Guanabara Bay and noted that dry periods are characterized by low ostracod densities associated to a possible decrease in size. This is in accordance to observations of macrobenthic ostracods, 
since, although densities increased throughout the rainy season, these were comparatively lower in the beginning of the dry period of the second year. Vilela et al. (2003) studied ostracods in the Guanabara Bay and reported high densities of C. salebrosa and Cyprideis sp. in more than $90 \%$ of the studied meiofaunal samples and proposed a possible tolerance of these species to pollution levels in the bay. Sola and Paiva (2001). Analyzed sublittoral macrobenthic densities along the year and observed no clear pattern of temporal variation for Cyprideis in the external area of the bay, even under conditions of exceptionally high waves (storm-surges). Van Der Ven et al. (2006) recorded unidentified ostracods in samples sieved through a $1 \mathrm{~mm}$ mesh, which is larger than the usual one $(500 \mu \mathrm{m})$ for macrobenthos. The marked seasonality, linked to the pluviometric period, suggests the existence of areas or zones inside the Guanabara Bay (Mayr et al., 1989; Paranhos et al., 1993; Paranhos and Mayr, 1993; Wandeness et al., 1997). This condition can be identified through the diverse bottom water dynamics, thus in accordance with established models of circulation observed in other tropical and subtropical estuaries (Amador, 1997; Kjerfve et al., 1997; Miranda et al., 2005). Density patterns of both studied species were different pluviometric periods. Seasonal variation in Cyprideis sp. was coherent throughout their entire spatial distribution. However, in C. salebrosa, it was possible to identify three different patterns of seasonal distribution, each linked to their relative location inside the bay. These differences can be attributed to the higher tolerance of Cyprideis sp. to marine environments, in comparison to C. salebrosa, which prefer brackish water, typical of inner estuarine areas (Anádon et al., 2002; Boomer and Eisenhauer, 2002; Ghiselli Junior et al., 2003; Vilela et al., 2003; Ruiz et al., 2005; Ghiselli Junior, 2006).

The results suggests a species-specific dynamic seasonal colonization/defaunation pattern on a spatial gradient along the bay (Echeverría et al., 2010; Pereira et al., 2013). Species recolonize seasonally available areas from areas were favorable conditions are more stable along the year and retreats back in a seasonal climate-induced pattern (Day et al., 1989; Gray and Elliot, 2009). Climatic changes may compromise these recolonization patterns and lead to a diminished recolonization capacity, if conditions remain unfavorable for longer periods (Frenzel and Boomer, 2005). These patterns also affects the exportation of propagules and recruits to other suitable points along the coastline (Gray and Elliot, 2009). These observed patterns may not be exclusive of ostracods and conclusions can probably be extended to other species with similar life cycles. The knowledge of the benthic communities dynamics in impacted coastal and estuarine ecosystems, associated to abiotics parameters is very important in the assessment or interpretation of natural or anthropic changes in coastal and estuarine ecosystems. It support the hypothesis of the seasonal dynamics in adult's Cyprideis populations seems to be a prerequisite for using this area in environmental monitoring studies, in which specific seasonal characteristics can lead to use as bioindicators on coastal and estuarine ecosystem.
In summary, the findings of the present study demonstrated that the seasonality of the rainfall regime clearly defines the dry and rainy periods and influence the macrobenthos. Different species show different distribution patterns, as observed for the distribution of Cyprideis salebrosa is different season throughout the bay, which is caused by the influence of the watershed contribution of the internal areas and the mixture with the tidal flow of the central channel. However, Cyprideis sp. distribution is seasonally and spatial homogen. Differences in densities and relationships to abiotic variables suggests that Cyprideis sp. presents a higher preference to marine conditions, while Cyprideis salebrosa prefers brackish environments, typical of estuaries (Figure 5, Table 1 and 2). This observation suggests the existence of distinct regimes within the Guanabara Bay caused by the seasonality of the pluviometric regime which influence the abiotic variables of the bottom water and sediment. Therefore, the knowledge of the seasonal dynamics of adult's Cyprideis spp. populations is fundamental for environmental monitoring, since the specific seasonal characteristics of the group can lead to misinterpretations when used as bioindicators.

\section{Acknowledgements}

The authors are grateful to the researchers Renato Olindo Ghiselli Jr, Simone N. Brandão and Cristianini Trescastro Bergue for sending papers, for suggestions and for taxonomic support. Furthermore, we appreciate the field support of Mariana Melão, Bruna Tovar Faro, Ricardo Bastos, Raquel Neves and Érico Demari e Silva, and anonymous reviewers for useful comments. The present work was part of the subproject "Estrutura das Comunidades da Macroendofauna Bentônica de Substrato Inconsolidado do Infralitoral" of the Project "Avaliação Ambiental da Baía de Guanabara, Rio de Janeiro, Brasil", coordinated by CENPES / Petrobrás.

\section{References}

ALONGI, D.M., 1989. Ecology of tropical soft-bottom benthos: a review with emphasis on emerging concepts. Revista de Biologia Tropical, vol. 37, pp. 85-100.

AMADOR, E., 2012. Bacia da Baía de Guanabara: caracteristicas geoambientais, formação e ecossistemas. Rio de Janeiro: Editora Interciência, $405 \mathrm{p}$.

AMADOR, E.S., 1997. Baía de Guanabara e ecossistemas periféricos: homem e natureza. Rio de Janeiro: Reproarte Gráfica e Editora Ltda, 539 p.

ANADÓN, P., GLIOZZI, E. and MAZZINI, I., 2002. Paleoenvironmental reconstruction of marginal marine environments from combined paleoecological and geochemical analyses on ostracods. In: J. HOLMES and A. CHIVAS, eds. The Ostracoda: applications in quaternary research. Washington: AGU 100, vol. 131, pp. 227-247. Geophysical Monograph. http://dx.doi. org/10.1029/131GM12.

ARMONIES, W. and HELLWIG, M., 1986. Quantitative extraction of living meiofauna from marine and brackish muddy 
sediments. Marine Ecology Progress Series, vol. 29, pp. 37-43. http://dx.doi.org/10.3354/meps029037.

BAPTISTA NETO, J.A., CRAPEZ, M., MCALISTER, J.J. and VILELA, C.G., 2005. Concentration and bioavailability of heavy metals in sediments from Niterói harbour (Guanabara Bay / S.E. Brazil). Journal of Coastal Research, vol. 21, pp. 811-817.

BENSON, R.H., 1959. Ecology of recent ostracodes of the Todos Santos Bay region, Baja California, Mexico. University of Kansas Paleontological Contributions, vol. 23, pp. 1-80.

BENSON, R.H., 1961. Ecology of ostracods assemblages. In: MOORE, R.C. and PITRAT, C.W., eds. Treatise on Invertebrate Paleontology: Part Q. Arthropoda 3, Crustacea, Ostracoda. New York: Geological Society of America, University of Kansas Press, pp. 56-63.

BERGIN, F., KUCUKSZEGIN, F., ULUTURHAN, E., BARUT, I.F., MERIC, E., AVSAR, N. and NAZIK, A., 2006. The response of benthic foraminifera and ostracoda to heavy metal pollution in Gulf of Izmir (Eastern Aegean Sea). Estuarine, Coastal and Shelf Science, vol. 66, no. 3-4, pp. 368-386. http://dx.doi.org/10.1016/j. ecss.2005.09.013.

BOOMER, I. and EISENHAUER, G., 2002, Ostracod faunas as palaeoenvironmental indicators in marginal marine environments. In: J. HOLMES and A. CHIVAS, eds. The Ostracoda: applications in quaternary research. Washington: AGU 100, vol. 131, pp. 135149, Geophysical Monograph. http://dx.doi.org/10.1029/131GM07.

BORCARD, D., GILLET, F. and LEGENDRE, P., 2011. Numerical Ecology with R. New York: Springer, 306 p. http:// dx.doi.org/10.1007/978-1-4419-7976-6.

BRANDÃO, S.N., ANGEL, M.V., KARANOVIC, I., PERRIER, V. and MEIDLA, T., 2018 [viewed 2018 August 15]. World Ostradoda Database [online]. Available from: http://www. marinespecies.org/ostracoda.

BRITO, E.M.S., GUYONEAUD, R., GOÑI-URRIZA, M., RANCHOU-PEYRUSE, A., VERBAERE, A., CRAPEZ, M.A.C., WASSERMAN, J.C.A. and DURAN, R., 2006. Characterization of hydrocarbonoclastic bacterial communities from mangrove sediments in Guanabara Bay, Brazil. Research in Microbiology, vol. 157, no. 8, pp. 752-762. http://dx.doi. org/10.1016/j.resmic.2006.03.005. PMid:16815684.

BROWN, S.S., GASTON, C.R., RAKOCINSKI, C.F. and HEARD, R.W., 2000. Effects of sediment contaminants and environmental gradients on macrobenthic community trophic structure in Gulf of Mexico Estuaries. Estuar, vol. 23, no. 3, pp. 411-424. http://dx.doi.org/10.2307/1353333.

CARBONEL, P., 1988. Ostracods and the transitions between fresh and saline Waters. In: P. DECKKER, J.P. COLIN and J.P. PEYPOUQUET, eds. Ostracoda in the earth sciences. Amsterdan: Elsevier, pp. 73-175.

CARREIRA, R., WAGENER, A.L.R., FILEMAN, T. and READMAN, J.W., 2001. Distribuição de coprostanol $(5 b(H)-$ COLESTAN-3b-OL) em sedimentos superficiais da Baía de Guanabara: indicador da poluição recente por esgotos domésticos. Quimica Nova, vol. 24, no. 1, pp. 37-42. http://dx.doi.org/10.1590/ S0100-40422001000100008.

CRAPEZ, M.A.C., TOSTA, Z.T., BISPO, M.G.S. and PEREIRA, D.C., 2000. Acute and chronic impacts caused by aromatic hydrocarbons on bacterial communities at Boa Viagem and Forte do Rio Branco beaches, Guanabara Bay, Brazil. Environmental
Pollution, vol. 108, no. 2, pp. 291-295. http://dx.doi.org/10.1016/ S0269-7491(99)00186-4. PMid:15092959.

CURRY, B.B., 1999. An environmental tolerance index for ostracodes as indicators of physical and chemical factors in aquatic habitats. Palaeogeography, vol. 148, no. 1-3, pp. 51-63. http://dx.doi.org/10.1016/S0031-0182(98)00175-8.

DAY, J., HALL, C., KEMP, W. and YÁÑEZ-ARANCIBIA, A., 1989. Estuarine ecology. 1st ed. New York: John Wiley \& Sons, $558 \mathrm{p}$.

DEBENAY, J.P., CARBONEL, P., MORZADEC-KERFOURN, M.T., CAZAUBON, A., DENÈFLE, M. and LÉZINE, A.M., 2003. Multi-bioindicador study of a small estuary in Vendée (France). Estuarine, Coastal and Shelf Science, vol. 58, no. 4, pp. 843-860. http://dx.doi.org/10.1016/S0272-7714(03)00189-6.

ECHEVERRÍA, C.A., NEVES, R.A.F., PESSOA, L.A. and PAIVA, P.C., 2010. Spatial and temporal distribution of the gastropod Heleobia australis in an eutrophic estuarine system suggests a metapopulation dynamics. Nature and Science, vol. 2, no. 08, pp. 860-867. http://dx.doi.org/10.4236/ns.2010.28108.

FRENZEL, P. and BOOMER, I., 2005. The use of ostracods from marginal marine, brackish waters as bioindicators of modem and Quaternary environmental changes. Palaeogeography, vol. 225, no. 1-4, pp. 68-92. http://dx.doi.org/10.1016/j.palaeo.2004.02.051.

GHISELLI JUNIOR, R.O., 2006. Comparação ecológica da fauna de Ostracoda entre a Enseada do Flamengo, Ubatuba (SP) e a Baía de Guanabara (RJ). São Paulo: Universidade de São Paulo, Instituto Oceanográfico, 95 p. PhD Thesis.

GHISELLI JUNIOR, R.O., CRISTOFI, M.G., EICHLER, B.B. and VILELA, C.G., 2003. Ecologia e Distribuição da fauna de ostracodes na Baía de Guanabara. In: II Congresso do Quaternário de Países de Línguas Ibéricas/IX Congresso da Associação Brasileira de estudos do Quaternário, 2003, Porto Seguro. Recife, PE: ABEQUA.

GRASSHOLF, K., KREMLING, K. and ERHARDT, M., 1999. Methods of seawater analysis. 3rd ed. Verlag: Wiley-VCH, 600 p.http://dx.doi.org/10.1002/9783527613984.

GRAY, J.S. and ELLIOT, M., 2009. Ecology of marine sediments. Oxford: Oxford Biology, 2nd ed. 256 p.

HOWE, H.V., KESLING, R.V. and SCOTT, H.W., 1961. Morphology of living Ostracoda. In: MOORE R.C.. Treatise on invertebrate paleontology. Part q, Arthropoda 3 (Crustacea, Ostracoda). Kansas: Geological Society of America and University, 442 p.

INSTITUTO NACIONAL DE METEREOLOGIA - INMET, 2008 [viewed 14 December 2008]. Available from: http://www. inmet.gov.br

KEATS, R.A. and OSHER, L.J., 2007. The macroinvertebrates of Ruppia (Widgeon Grass) beds in a small Maine Estuary. Northeastern Naturalist, vol. 14, no. 3, pp. 481-491. http://dx.doi. org/10.1656/1092-6194(2007)14[481:TMORWG]2.0.CO;2.

KESLING, R.V., 1961, Reproduction of ostracoda. In: R.C. MOORE. Treatise on invertebrate paleontology. Part Q, Arthropoda 3 (Crustacea, Ostracoda). Lawrence: Geological Society of America and University of Kansas Press, 442 p.

KJERFVE, B., RIBEIRO, C.H.A., DIAS, G.T.M., FILIPO, A.M. and QUARESMA, V.S., 1997. Oceanographic characteristics of an impacted coastal bay: baía de Guanabara, Rio de Janeiro, Brazil. Continental Shelf Research, vol. 17, no. 13, pp. 1609-1643. http://dx.doi.org/10.1016/S0278-4343(97)00028-9. 
KNAUSS, J.A., 2005. Introduction to physical oceanography. 2nd ed. Long Grove: Waveland Pr Inc, 320 p.

LITTLE, C., 2000. The biology of soft shores and estuaries. Oxford: Oxford University Press, $264 \mathrm{p}$.

MACHADO, W., SILVA-FILHO, E.V., OLIVEIRA, R.R. and LACERDA, L.D., 2002. Trace metal retention in mangrove ecosystems in Guanabara Bay, SE Brazil. Marine Pollution Bulletin, vol. 44, no. 11, pp. 1277-1280. http://dx.doi.org/10.1016/ S0025-326X(02)00232-1. PMid:12523527.

MAGALHÃES, T.R.F., NEVES, R.A.F., VALENTIN, J.V. and FIGUEIREDO, G.M., 2014. Do the changes in temperature and light affect the functional response of the benthic mud snail Heleobia australis (Mollusca: grastropoda)? Anais da Academia Brasileira de Ciências, vol. 86, no. 3, pp. 1197-1205. http:// dx.doi.org/10.1590/0001-3765201420130093. PMid:25014915.

MARENGO, J.A., JONES, R., ALVES, L.M. and VALVERDE, M.C., 2009. Future change of temperature and precipitation extremes in South America as derived from the PRECIS regional climate modeling system. International Journal of Climatology, vol. 15, no. 15, pp. 2241-2255. http://dx.doi.org/10.1002/joc.1863.

MAYR, L.M., TENENBAUM, D.R., VILLAC, M.C., PARANHOS, R., NOGUEIRA, C.R., BONECKER, S.L.C. and BONECKER, A.C.T., 1989. Hydrobiological characterization of Guanabara Bay. In: O. MAGOON and C. NEVES, eds. Coastlines of Brazil. New York: American Society of Civil Engineers, pp. 124-138.

MENDONÇA FILHO, J.G., MENEZES, T.R., OLIVEIRA, E.A. and LEMMA, M.B., 2003. Caracterização da contaminação por petróleo e seus derivados na Baía de Guanabara: Aplicação de técnicas Organogeoquímicas e Organopetrográfica. Anuário do Instituto de Geociências, vol. 26, pp. 55-64.

MENICONI, M.F.G., SILVA, T.A., FONSECA, M.L., LIMA, S.O.F., LIMA, E.F.A., LAVRADO, H.P. and FIGUEIREDO JUNIOR, A.G., 2012a. Sintese do conhecimento ambiental: biodiversidade. Baía de Guanabara: Petrobrás, 479 p.

MENICONI, M.F.G., SILVA, T.A., FONSECA, M.L., LIMA, S.O.F., LIMA, E.F.A., LAVRADO, H.P. and FIGUEIREDO JUNIOR, A.G., 2012b. Síntese do conhecimento ambiental: ambiente e influência antrópica. Baía de Guanabara: Petrobrás, $337 \mathrm{p}$.

MEZQUITA, F., HERNANDEZ, R. and RUEDA, J., 1999. Ecology and distribution of ostracods in a polluted Mediterranean river. Palaeoecology, vol. 148, no. 1-3, pp. 87-103. http://dx.doi. org/10.1016/S0031-0182(98)00177-1.

MIRANDA, L.B., BÉRGAMO, A.L. and CASTRO, B.M., 2005. Interactions of river discharge and tidal modulation in a tropical estuary, NE Brazil. Ocean Dynamics, vol. 55, no. 5-6, pp. 430440. http://dx.doi.org/10.1007/s10236-005-0028-z.

MODIG, H. and ÓLAFSSON, E., 1998. Responses of Baltic benthic invertebrates to hypoxic events. Journal of Experimental Marine Biology and Ecology, vol. 229, no. 1, pp. 133-148. http:// dx.doi.org/10.1016/S0022-0981(98)00043-4.

NAGORSKAYA, L. and HEYSER, D., 2005. Habitat diversity and ostracod distribution patterns in Belarus. Hydrobiologia, vol. 538, no. $1-3$, pp. 167-178. http://dx.doi.org/10.1007/s10750004-4959-z.

NEVES, R.A.F., ECHEVERRÍA, C.A., PESSOA, L.A., PAIVA, P.C., PARANHOS, R. and VALENTIN, J.L., 2013. Factors influencing spatial patterns of molluscs in a eutrophic tropical bay. Journal of the Marine Biological Association of the United
Kingdom, vol. 93, no. 3, pp. 577-589. http://dx.doi.org/10.1017/ S0025315412001105.

PARANHOS, R. and MAYR, L.M., 1993. Seasonal patterns of temperature and salinity in Guanabara Bay, Brazil. Frenes. Environ. Bul., vol. 2, pp. 647-652.

PARANHOS, R., ANDRADE, L., MENDONÇA-HAGLER, L.C. and PFEIFFER, W.C., 2001. Coupling bacterial abundance with production in a polluted tropical coastal bay. Oecologia Brasiliensis, vol. 9, no. 01, pp. 117-132. http://dx.doi.org/10.4257/ oeco.2001.0901.09.

PARANHOS, R., MAYR, L.M., LAVRADO, H.P. and CASTILHO, P.C., 1993. Temperature and salinity trends in Guanabara Bay (Brazil) from 1980 to 1990. Arquivos de Biologia e Tecnologia, vol. 36, pp. 685-694.

PARANHOS, R., PEREIRA, A.P. and MAYR, L.M., 1998. Diel variability of water quality in a tropical polluted bay. Environmental Monitoring and Assessment, vol. 50, no. 2, pp. 131-141. http:// dx.doi.org/10.1023/A:1005855914215.

PARSONS, T.R., MAYTA, Y. and LALLI, C.M., 1984. A manual of chemical and biological methods for seawater analysis. 2nd ed. Oxford: Pergamon Press. 173 p.

PASSADORE, C., GIMÉNEZ, L. and ACUÑA, A., 2007. Composition and intra-annual variation of the macroinfauna in the estuarine zone of the Pando Stream (Uruguay). Brazilian Journal of Biology $=$ Revista Brasileira de Biologia, vol. 67, no. 2, pp. 197-202. http://dx.doi.org/10.1590/S1519-69842007000200003. PMid:17876428.

PEREIRA, V.P.P., PESSOA, L.A., FREITAS, M.A.V. and ECHEVERRÍA, C.A., 2013. Recovery process on soft-bottom macrobenthic communities after artificial disturbance in tropical polluted estuary (Guanabara Bay, Rio de Janeiro, Brazil). Open J. Mar. Sci., vol. 3, no. 04, pp. 161-166. http://dx.doi.org/10.4236/ ojms.2013.34018.

PRANDLE, D., 2009. Estuaries: Dynamics, Mixing, Sedimentation and Morphology. New York: Cambridge University Press, 236 p. http://dx.doi.org/10.1017/CBO9780511576096.

PRITCHARD, D.W., 1955. Estuarine Circulation Patterns. Proceedings of the American Society of Civil Engineers, vol. 81, pp. 1-11.

PRITCHARD, D.W., 1967. What is an Estuary: physical viewpoint. In: G.H. LAUFF, ed. Estuaries. Washington: American Association for the Advancement of Science. vol. 83, pp. 3-5.

QUARESMA, V.S., DIAS, G.T.M. and BAPTISTA NETO, J.A., 2000. Caracterização da ocorrência de padrões de sonar de varredura lateral e sísmica de alta freqüência $(3,5$ e 7,0 kHz) na porção sul da Baía de Guanabara - RJ. Revista Brasileira de Geofisica, vol. 1, no. 2, pp. 201-214. http://dx.doi.org/10.1590/ S0102-261X2000000200008.

QUINN, G.P. and KEOUGH, M.J., 2003. Experimental design and data analysis for biologists. Cambridge: Cambridge Univ. Press, $537 \mathrm{p}$.

R DEVELOPMENT CORE TEAM, 2008. $R$ : A language and environment for statistical computing. Vienna: R Foundation for Statistical Computing.

RAKOCINSKI, C.F., BROWN, S.S., GASTON, G.R., HEARD, R.W., WALKER, W.W. and SUMMERS, J.K., 1997. Macrobenthic responses to natural and contaminant-related gradients in northern Gulf of Mexico estuaries. Ecological Applications, vol. 7, no. 4, pp. 
1278-1298. http://dx.doi.org/10.1890/1051-0761(1997)007[1278:MR TNAC]2.0.CO;2.

ROSENBERG, R., 2001. Marine benthic faunal successional stages and related sedimentary activity. Scientia Marina, vol. 65, no. S2, pp. 107-119. http://dx.doi.org/10.3989/scimar.2001.65s2107.

RUIZ, F., ABAD, M., BODERGAT, A.M., CARBONEL, P., RODRÍGUEZ-LÁZARO, J. and YASUHARA, M., 2005. Marine and brackish-water ostracods as sentinels of anthropogenic impacts. Earth-Science Reviews, vol. 72, no. 1-2, pp. 89-111. http://dx.doi.org/10.1016/j.earscirev.2005.04.003.

RUIZ, F., ABAD, M., OLÍAS, M., GALÁN, E., GONZÁLEZ, I., AGUILÁ, E., HAMOUMI, N., PULIDO, I. and CANTANO, M., 2006. The present environmental scenario of the Nador Lagoon (Morocco). Environmental Research, vol. 102, no. 2, pp. 215-229. http://dx.doi.org/10.1016/j.envres.2006.03.001. PMid:16624276.

RUIZ, F., GONZÁLEZ-REGALADO, M.L. and MUNÕZ, J.M., 1997. Multivariate analysis applied to total and living fauna: seasonal ecology of recent benthic Ostracoda off the North Cádiz Gulf coast (southwestern Spain). Marine Micropaleontology, vol. 31, no. 3-4, pp. 183-203. http://dx.doi.org/10.1016/S03778398(96)00060-6.

RUIZ, F., GONZÁLEZ-REGALADO, M.L., BORREGO, J., ABAD, M. and PENDÓN, J.G., 2004. Ostracoda and foraminifera as short-term tracers of environmental changes in very polluted areas: the Odiel Estuary (SW Spain). Environmental Pollution, vol. 129, no. 1, pp. 49-61. http://dx.doi.org/10.1016/j. envpol.2003.09.024. PMid:14749069.

SCHRATZBERGER, M., DANIEL, F., WALL, C.M., KILBRIDE, R., MACNAUGHTON, S., BOYD, S.E., REES, H.L., LEE, K. and SWANNELL, R.P.J., 2003. Response of estuarine meio-andmacrofauna to in situ bioremediation of oil-contaminated sediment. Marine Pollution Bulletin, vol. 46, no. 4, pp. 430-443. http:// dx.doi.org/10.1016/S0025-326X(02)00465-4. PMid:12705916.
SOLA, M.C.R. and PAIVA, P.C., 2001. Variação temporal da macrofauna bentônica sublitoral da praia da Urca (RJ) após à ocorrência de ressacas. Brazilian Journal of Oceanography, vol. 49, no. 1-2, pp. 137-142. http://dx.doi.org/10.1590/S167987592001000100012 .

VALENTIN, J.L., TENENBAUM, D.R., BONECKER, A.C.T., BONECKER, S.L.C., NOGUEIRA, C.R. and VILLAC, M.C., 1999. O sistema planctônico da Baía de Guanabara: síntese do conhecimento. In: S.H.G. SILVA and H.P. LAVRADO, eds. Ecologia de ambientes costeiros do estado do Rio de Janeiro. Rio de Janeiro: PPGE-UFRJ, pp. 35-59. Série Oecologia Brasiliensis, no. 7.

VALIELA, I., 1995. Marine Ecological Processes. 2nd ed. New York: Springer-Verlag, 686 p. http://dx.doi.org/10.1007/978-14757-4125-4.

VAN DER VEN, M., SOARES-GOMES, A. and TAVARES, M., 2006. Taxocene of crustacea at a highly impacted bay: Guanabara Bay, southeastern Brazil. Journal of Coastal Research, vol. 39, pp. 1135-1139.

VAN MORKHOVEN, F.P.C.M., 1962. Post-Palaeozoic Ostracoda: their morphology, taxonomy and economic use. Amsterdam: Elsevier Publishing Company, vol. 1, 204 p.

VILELA, C. G., SANJINÉS, A. E. S., GHISELLI JUNIOR, R. O., MENDONÇA FILHO, J. G., BAPTISTA NETO, J. A. and BARBOSA, C. F., 2003. Search for biondicators of pollution in the Guanabara Bay: integrations of ecologic patterns. Anuário do Instituto de Geociências, vol. 26, pp. 25-35.

VILELA, C.G., FIGUEIRA, B.O., MACEDO, M.C. and BAPTISTA NETO, J.A., 2013. Late Holocene evolution and increasing pollution in Guanabara Bay. Marine Pollution Bulletin, vol. 79, no. 1-2, pp. 175-187.

WANDENESS, A.P., MATTOS, M.A.R. and NOGUEIRA, C.S.R., 1997. Copepoda (Crustacea) of Guanabara Bay, Rio de Janeiro. Brazilian Archives of Biology and Technology, vol. 40, pp. 377-381. 